JURNAL KETAHANAN NASIONAL

Vol. 26, No. 1, April 2020, Hal 1-22

DOI:http://dx.doi.org/ 10.22146/jkn.51109

ISSN:0853-9340(Print), ISSN:2527-9688(Online)

Online sejak 28 Desember 2015 di :http://jurnal.ugm.ac.id/JKN

VOLUME 26

No. 1, April 2020

Halaman 1-22

\title{
Literasi Berita Hoaxs Di Internet Dan Implikasinya Terhadap Ketahanan Pribadi Mahasiswa \\ (Studi Tentang Penggunaan Media Sosial Pada Mahasiswa STT Adisutjipto Yogyakarta)
}

\author{
Abdul Haris Subarjo \\ Prodi Teknik Mesin, Sekolah Tinggi Teknologi Adisutjipto, Yogyakarta, Indonesia \\ email: ab.haris.79@gmail.com \\ Wita Setianingsih \\ Jurusan Pendidikan IPA, FMIPA, Universitas Negeri Yogyakarta, Indonesia \\ email: wita@uny.ac.id
}

\begin{abstract}
The use of the internet has consequences for ways of thinking and ways of acting in the face of a variety of information presented, a variety of information flows swiftly with various interests. The ease of providing information through social media has both positive and negative impacts. Often information on various social media causes noise, unrest and can divide the public and be hoax news. Various truths that have not been investigated are displayed. Literacy is one of the components highlighted by countries in the world. The level of literacy of a country shows the ability of its citizens to study, study, disseminate information and make decisions and act on that information. STTA is an educational institution which consists of the academic community. Based on this, it is necessary to conduct research that reveals the literacy profile of the academic community, namely STTA students, on the spread of hoax news in the internet in relation to national resilience. Data are collected by questionnaire and library research. The results indicated that the condition of literacy has the implication on personal resilience of students which have a close connection with national resilience. Students without a good understanding, especially about hoax news can cause destruction in their personal resilience and potentially disturbing the national resilience.
\end{abstract}

Keywords: Literacy, Hoax News, Personal Resilience of Students, National Resilience.

\begin{abstract}
ABSTRAK
Penggunaan internet membawa konsekuensi pada cara berfikir dan cara bertindak dalam menghadapi beragam informasi yang disajikan, beragam informasi mengalir deras dengan beragam kepentingan. Kemudahan untuk memberikan informasi melalui media sosial memberikan dampak positif dan negatif. Seringkali informasi di berbagai media sosial menimbulkan kegaduhan, keresahan dan dapat memecah belah masyarakat dan merupaka berita hoaks. Beragam kabar yang belum diselidiki kebenarannya terpampang. Literasi merupakan salah satu komponen yang disorot oleh negara-negara di dunia. Tingkat literasi suatu negara menunjukkan kemampuan dari warga negaranya dalam menelaah, mengkaji, menyebarluaskan suatu informasi serta mengambil keputusan dan bertindak berdasarkan informasi tersebut. Sekolah Tinggi Teknologi Adisutjipto (STTA) merupakan sebuah lembaga Pendidikan tinggi yang di dalamnya beranggotakan masyarakat akademik. Berdasarkan hal tersebut penelitian ini dilakukan untuk mengungkap bagaimana profil literasi mahasiswa STTA terhadap penyebaran berita hoaxs di internet dalam kaitannya dengan ketahanan nasional. Metode pengumpulan data dilakukan dengan kuesioner dan penelusuran literatur. Data tentang literasi informasi dianalisis untuk mengetahui kondisi ketahanan pribadi
\end{abstract}


mahasiswa. Hasil penelitian menunjukkan bahwa kondisi literasi berita hoaxs berimplikasi terhadap ketahanan pribadi mahasiswa yang terkait erat dengan ketahanan nasional. Mahasiswa tanpa pemahaman yang baik terhadap berita hoaxs dapat merusak ketahanan pribadi mereka dan berpotensi mengganggu ketahanan nasional.

\section{Keywords: Literasi, Berita Hoaxs, Ketahanan Pribadi Mahasiswa, Ketahanan Nasional.}

\section{PENGANTAR}

Pada awal tahun 2000-an apabila ingin mengetahui berita tentang peristiwa di daerah lain membutuhkan waktu yang cukup lama. Bahkan kalau jarak kejadiannya berkilokilo meter dari tempat tinggal kita, untuk mendapatkan beritanya membutuhkan waktu berhari-hari. Di masa sekarang proses tayangan berita menjadi singkat. Jarak yang jauh tidak lagi menjadi penghambat untuk mengetahui berbagai berita/informasi dengan cepat, dengan beaya yang juga relatif kecil. Untuk mengetahui informasi tidak memerlukan kemampuan tertentu, karena setiap orang dapat dengan mudah mengakses informasi.

Dalam rangka mewujudkan warga negara yang aktif, diperlukan civic literacy yang dimulai dari pengetahuan, pemahaman, dan kemauan untuk mempengaruhi pemerintahan atau proses politik. Bidang keilmuwan Pendidikan Pancasila dan Kewarganegaraan di Indonesia, menyajikan pembelajaran yang berfokus untuk membentuk warganegara yang berkompeten, berkarakter, menjiwai hakhak dan kewajiban sesuai falsafah Pancasila dan UUD 1945 (Budimansyah dalam Rudi Setiawan, 2019)

Penelitian tentang literasi telah dilakukan oleh Ronny Scherer dan Fazilat Siddiq (2019) mengenai meta-analisis dengan melakukan sintesis hubungan antara ukuran status sosial ekonomi (SES) dan literasi teknologi informasi dan komunikasi (TIK) siswa, Pemodelan yang digunakan ialah model efek acak tiga tingkat di 32 independen. Sampel siswa K-12 menyediakan 75 koefisien korelasi, identifikasi positif, signifikan, dan korelasi kecil, $\mathrm{r}^{-}=$ 0,214, 95\% CI [0,184, 0,244]. Korelasi ini bervariasi antara studi dan dimoderatori oleh jenis ukuran SES, jenis penilaian literasi TIK, kategori luas keterampilan TIK yang dinilai, penilaian kewajaran tes, dan pengambilan sampel prosedur yang digunakan. Temuan dari meta-analisis ini menunjukkan bahwa literasi TIK siswa berbeda antara kelompok status sosial ekonomi, sehingga menunjukkan celah dalam domain TIK.

Penelitian ini difokuskan pada profil literasi mahasiswa terhadap penyebaran beritaberita hoaks di internet dan hubungannya dengan ketahanan pribadi mahasiswa dan ketahanan nasional. Objek penelitian ini hanya dibatasi pada masyarakat akademik yaitu mahasiswa Sekolah Tinggi Teknologi Adisutjipto (STTA) dan lebih spesifik lagi pada mahasiswa dari 2 program studi dari program studi teknik mesin yang mengikuti mata kuliah kewarganegaraan tahun akademik 2018/2019 serta mahasiswa dari program studi teknik penerbangan yang mengikuti perkuliahan kewarganegaraan pada tahun akademik 2018/2019. Manfaat dari penelitian ini adalah memperoleh data profil tingkat literasi mahasiswa terhadap penyebaran beritaberita hoaxs di internet dan hubungannya dengan ketahanan pribadi mahasiswa dari dua program studi tersebut.

Metode penelitian ini meliputi ketentuan dan prosedur sebagai berikut:

Pertama, Jenis penelitian. Penelitian ini merupakan suatu penelitian kualitatif deskriptif yang mengungkap profil literasi 
Abdul Haris Subarjo, Wita Setianingsih -- Literasi Berita Hoaxs Di Internet Dan Implikasinya Terhadap Ketahanan Pribadi Mahasiswa

(Studi Tentang Penggunaan Media Sosial Pada Mahasiswa STT Adisutjipto Yogyakarta)

masyarakat akademik, khususnya mahasiswa STTA terhadap penyebaran informasi hoaxs di internet dan hubungannya dengan ketahanan pribadi mahasiswa dan ketahanan nasional.

Kedua, Populasi dan sampel penelitian. Populasi dan sampel penelitian dalam penelitian ini sebagai populasi adalah mahasiswa STTA dan sampel dalam penelitian adalah mahasiswa STTA yang berasal dari dua program studi yaitu teknik mesin dan teknik penerbangan.

Ketiga, Teknik pengambilan sampel. Populasi yakni mahasiswa STTA sebagai masyarakat akademik dari populasi itu diambil sampel. Sampel diambil dengan teknik purposive cluster sampling pada mahasiswa STTA, dengan program studi sebagai clusternya.

Keempat, Instrumen penelitian. Penelitian ini menggunakan intrumen penelitian untuk mengumpulkan dan memperoleh informasi yang diperlukan. Instrumen yang digunakan adalah angket dan tes tulis.

Kelima, Teknik analisis data. Rangkaian analisis data meliputi kegiatan kategorisasi data dengan mendeskripsikan setiap kategori, sinkronisasi temuan, merumuskan temuantemuan, kemudian perumusan kesimpulan.

\section{PEMBAHASAN}

\section{Pengertian Internet}

Berbagai informasi atau kejadian di wilayah lain dalam waktu singkat dapat diperoleh. Bahkan peristiwa di negara lain yang jauh juga dapat dalam waktu singkat bisa diperoleh. Hal ini merupakan kenyataan nyata dan bukan mimpi lagi. Kenyataan ini dapat terwujud dengan adanya internet. Dengan adanya internet kebiasaan masyarakat menjadi berubah. Internet yang tadinya hanya dapat dinikmati oleh orang tertentu saja saat ini bahkan menjadi suatu kebutuhan.

Teknologi internet sekarang menjadi kebutuhan, saat ini setiap orang memanfaatkan internet. Pemanfaatan internet tidak hanya berasal dari kalangan berpendidikan tinggi, orang yang memiliki banyak uang serta eksekutif perusahaan, namun internet juga dimanfaatkan oleh masyarakat tanpa memandang status dan kemampuan akademik. Bahkan masyarakat dengan pendidikan formal rendah serta memiliki kemampuan finansial terbatas juga memiliki akses internet. Karena untuk mengakses internet hanya dibutuhkan sebuah smartphone dengan harga yang relatif terjangkau oleh kebanyakan masyarakat saat ini dengan paket data internet atau menggunakan jaringan wifi yang berada di area public. Bagi akademisi kampus dan sekolah internet lazim digunakan. Biasanya bagi kalangan akademisi internet dipergunakan untuk mencari informasi dan mencari sumbersumber pustaka dalam rangka mengerjakan tugas-tugasnya.

Internet merupakan sebuah jaringan komputer yang dapat digunakan secara luas oleh masyarakat. Internet tidak hanya dapat diakses oleh suatu masyarakat di daerah tertentu yang terbatas oleh ruang dan waktu, namun juga dapat diakses oleh masyarakat pada tempat yang berlainan dan tidak terbatas pada waktu tertentu dan peralatan komputer tertentu. Sebagai contoh: seorang penulis artikel menuliskan karyanya di kota Yogyakarta dan menggunakan komputernya, ternyata masyarakat lain dapat mengakses tulisan penulis tersebut pada kota yang lain dan negara yang berlainan pula, misal tulisan penulis tersebut dapat diakses oleh pembaca di kota Washington di negara Amerika Serikat pada hari dan jam yang bersamaan pada 
saat penulis mempublish tulisannya. Hal ini menjadikan berbagai peristiwa yang terjadi di belahan dunia dapat diketahui oleh penduduk di belahan dunia yang berlainan. Sehingga menyebabkan jarak yang berjauhan bukan menjadi sebuah kendala utama. Teknologi internet berkembang cukup pesat terutama berhubungan dengan alat komunikasi. (Subarjo, Abdul Haris. 2016)

Melalui internet pernyataan bahwa dunia berada dalam genggaman tidak lagi sekedar wacana. Karena dengan internet kita dapat melakukan dan mendapatkan apapun, dari mulai hal yang berguna maupun hal yang tidak bermanfaat. Dengan internet kita juga dapat menambah relasi atau justru menimbulkan konflik. Penggunaan internet di berbagai kalangan masyarakat dan dari berbagai tingkat pendidikan membawa konsekuensi pada cara berfikir dan cara bertindaknya dalam menghadapi beragam informasi yang disajikan. Beraneka ragam tingkat pendidikan dan pekerjaannya juga memberikan andil dalam menyikapinya. Seiring dengan kebutuhan para penggunanya maka muncullah beragam aplikasi dengan pemanfaatan internet. Termasuk aplikasi yang digunakan untuk berkomunikasi dengan berbagai media sosial. Saling bertukar informasi dengan media sosial di internet dapat berdampak positif atau negatif bagi pelaku maupun bagi pihak lain.

Dampak positifnya, informasiinformasi penting dapat segera diketahui dan ditindaklanjuti sebagai pengambilan keputusan, namun tidak semua informasi yang diperoleh sesuai kenyataan terkadang juga terdapat informasi yang tidak benar atau hoaxs. Istilah berita hoaxs sering kita dengar dikalangan masyarakat merupakan istilah untuk menyebut bahwa informasi tersebut tidak jelas kebenaran berita serta pemberi informasi. Saat ini setiap orang dapat memberikan informasi, pendapat maupun tanggapan tanpa membutuhkan kemampuan khusus. Pemerintah berupaya memberikan rambu-rambu melalui undangundang informasi teknologi elektronik.

Dalam kenyataannya seringkali informasi yang ada di media sosial tersebut dapat berdampak buruk. Dalam media sosial terdapat informasi yang diragukan validitasnya. Sayangnya masyarakat mudah percaya tanpa upaya untuk mencerna secara mendalam dan mencari informasi yang dapat lebih dipercaya kebenarannya sebagai informasi pembanding. Terkadang berita yang benar justru terlambat sampai dan tidak dipercaya kebenarannya oleh masyarakat. Untuk menelaah dan mencerna kebenaran berita, masyarakat memerlukan kemampuan literasi. Literasi merupakan salah satu komponen yang disorot oleh negaranegara di dunia. Tingkat literasi negara adalah kemampuan warga dalam menelaah, mengkaji, menyaring, menyebarluaskan suatu informasi serta mengambil keputusan dan bertindak berdasarkan informasi tersebut.

Menurut Zuriah dalam Wellyana (2019) pendidikan kewarganegaraan atau citizenship education merupakan salah satu instrumen fundamental dalam sistem pendidikan nasional yang berperan sebagai pembentuk karakter bangsa (nation character building) di tengah karakteristik bangsa yang serba pluralistik. Untuk membentuk warga negara yang berperan aktif dalam pemerintahan, diperlukan strategi untuk meningkatkan kreativitas warga negara dalam hidup bernegara.

\section{Pengertian Literasi}

Literasi dapat dimaknai sebagai suatu kemampuan mengetahui pengetahuan yang 
Abdul Haris Subarjo, Wita Setianingsih -- Literasi Berita Hoaxs Di Internet Dan Implikasinya Terhadap Ketahanan Pribadi Mahasiswa

(Studi Tentang Penggunaan Media Sosial Pada Mahasiswa STT Adisutjipto Yogyakarta)

meliputi semua keterampilan mengenai bagaimana berfikir dengan menggunakan sumber-sumber pengetahuan, yang kemudian akan diolah atau implementasikan (Rinjani dalam Puryanti Y.A.T, 2019). keterampilan literasi emergensi berhubungan langsung dengan konsep diri pembaca tetapi tidak dengan minat literasi (Bente R. Walgermo, 2018). Paul Zurkowski mengemukakan orang yang literat informasi adalah orang-orang yang terlatih dalam aplikasi sumberdaya dalam pekerjaan (Behrens dalam Subarjo, Abdul Haris. 2017)

Bangsa yang besar memiliki masyarakatnya yang literat, berperadaban tinggi dan aktif. Keliterasian dalam konteks tersebut bukan hanya bagaimana bebas buta aksara, namun juga warga memiliki kecakapan untuk bersaing, bersanding dengan bangsa lain (Effendy dalam Puryanti Y.A.T, 2019).

Menurut Word Bank Economic Forum (2015) dalam Puryanti Y.A.T, (2019), enam macam komponen-komponen literasi:

(1) Literasi linguistic (baca-tulis)

(2) Literasi bilangan (numeracy),

(3) Literasi sains,

(4) Literasi teknologi informasi dan komunikasi,

(5) Literasi keuangan,

(6) Literasi budaya dan kewargaan.

Tujuh prinsip-prinsip pendidikan literasi Kern (2000) yaitu:

(1) Literasi melibatkan interpretasi, penulis/ pembicara serta pembaca/pendengar berkontribusi dalam interpretasi.

(2) Literasi melibatkan kolaborasi, kerjasama kesepahaman antara pihak penulis/ pembicara dan pembaca/ pendengar

(3) Literasi melibatkan konvensi, maksudnya kesepakatan tidak universal berkembang melalui penggunaan untuk tujuan individual.

(4) Literasi berkaitan pengetahuan kultural, orang diluar sistem budaya rentan salah dipahami oleh orang yang berada di sistem karena dalam memahami informasi dengan nilai dan keyakinan tertentu.

(5) Literasi melibatkan pemecahan masalah, kata melekat pada linguistik dan situasi, sehingga ada tindakan membayangkan hubungan antara kata, frase, kalimat, unit makna, teks, dunia untuk memecahkan masalah.

(6) Literasi melibatkan refleksi dan refleksi diri. Mendudukkan diri dalam situasi komunikasi memikirkan apa, bagaimana dan mengapa mengatakan sesuatu.

(7) Literasi melibatkan penggunaan bahasa. Literasi tidak terbatas pada sistem-sistem bahasa (lisan/tertulis) namun terdapat syarat pengetahuan bagaimana bahasa digunakan tertulis maupun lisan.

Penelitian mengenai literasi yang dilakukan oleh José P. Pezoa, dkk (2019) telah meneliti bagaimana minat baca anakanak (seperti yang dilaporkan oleh orang tua mereka) dan praktik-praktik literar orang tua tetap stabil atau berubah seiring waktu, serta hubungan yang saling melintang antara minat baca dan praktik literasi orang tua dari awal taman kanak-kanak hingga akhir taman kanak-kanak. Hasilnya menunjukkan bahwa dalam keluarga Chili berpenghasilan rendah ini, lebih mungkin untuk membaca minat untuk memprediksi praktik orang tua daripada sebaliknya. Penelitian literasi lainnya dilakukan oleh Serafina Pastore dan Heidi L. Andrade (2019) dengan tujuan menyajikan model literasi penilaian yang diperbarui dan diperluas yang mewakili 
tiga kunci aspek literasi penilaian dalam konteks. Literasi penilaian telah diakui sebagai penting bagi guru karena membantu mereka menggunakan informasi tentang pembelajaran siswa untuk mengajar secara lebih efektif dengan menanggapi kebutuhan belajar siswa.

Penelitian yang dilakukan oleh Juan D. Borrero, dkk., dalam jurnal Computers in Human Behavior (2014) mengemukaan bahwa ekspektasi upaya, pengaruh sosial, dan ekspektasi kinerja secara signifikan mempengaruhi niat siswa untuk menggunakan situs jejaring sosial (SNS) untuk partisipasi ekspresif dalam gerakan sosial internet.

\section{Ketahanan Nasional}

Ketahanan nasional merupakan kondisi dinamik Bangsa Indonesia yaitu keuletan, ketangguhan untuk mengembangkan kemampuan, kekuatan nasional, dalam menghadapi serta mengatasi tantangan, ancaman, hambatan, gangguan dari dalam maupun luar negeri, secara langsung maupun tidak dan berpotensi berbahaya untuk kelangsungan hidup bangsa dan negara Indonesia berdasarkan Pancasila dan UUD 45. Untuk menciptakan kondisi yang mendukung ketahanan nasional salah satunya adalah melakukan filter informasi di masyarakat. Ketahanan masyarakat dengan kemampuan literasi informasi yang baik dapat mendukung Ketahanan Nasional, karena mereka tidak mudah terhasut oleh ajakan dan berita yang berpotensi memecah belah persatuan. (Subarjo, Abdul Haris. 2017). Kita dapat melihat contohnya pada kasus hoaxs yang terjadi pada berita di Papua dan Papua Barat yang bernuansa Suku, Agama, Ras, Antar Golongan. Dengan mudahnya berita kasus itu diputar balikkan sesuai kepentingan pihakpihak tertentu yang akibatnya mengancam persatuan dan kesatuan serta berdampak lebih besar lagi mengancam ketahanan nasional.

Konsepsi ketahanan nasional merupakan konsepsi geostrategi sebuah bangsa. Ketahanan nasional mamiliki kerangka fungsi ganda, yaitu melindungi aspek-aspek alamiah (geografi, penduduk, dan sumberdaya alam) dan aspek-aspek sosial (ideologi, politik, ekonomi, sosial-budaya, dan pertahanan/ keamanan; atau sering disingkat dengan Ipoleksosbudhankam). Ketahanan nasional dapat dikatakan sebagai konsep survival agar mampu bertahan sebagai bangsa yang berdaulat (Suradinata dalam Adi S., 2018). Apabila dilihat secara khusus pada ketahanan bidang sosial-budaya, maka persoalannya berkisar pada kemampuan masyarakat untuk membina kehidupan yang rukun sejahtera dan tetap berkepribadian Indonesia dalam masyarakat majemuk sebagai perwujudan Bhineka Tungal Ika. Pondasi cukup tangguh pada gatra sosial budaya terlihat dari kesadaran akan pentingnya persatuan dan kesatuan bangsa tertanam dalam masyarakat (Anwar S., 2019). Tingkat literasi masyarakat termasuk dalam masalah ketahanan sosial-budaya. Literasi merupakan kemampuan meliputi semua keterampilan berfikir dengan menggunakan sumber-sumber pengetahuan, yang kemudian diolah dan implementasikan (Rinjani dalam Puryanti Y.A.T, 2019). Seseorang yang memiliki literasi informasi yang baik maka ia dapat mengambil sikap yang positif dalam menyikapi informasi yang didapatkan dan ia dapat memperkuat ketahanan pribadinya dalam kehidupan sosial budaya.

Upaya untuk mewujudkan ketahanan nasional dapat dilakukan melalui bela negara. Istilah bela negara, dapat ditemukan dalam rumusan Pasal 27 ayat 3UUD NKRI 1945. Pasal 27 ayat 3 menyatakan "Setiap warga 
Abdul Haris Subarjo, Wita Setianingsih -- Literasi Berita Hoaxs Di Internet Dan Implikasinya Terhadap Ketahanan Pribadi Mahasiswa (Studi Tentang Penggunaan Media Sosial Pada Mahasiswa STT Adisutjipto Yogyakarta)

negara berhak dan wajib ikut serta dalam upaya pembelaan negara". Selain itu, setiap warga negara dapat turut serta dalam setiap usaha pembelaan negara sesuai dengan kemampuan dan profesi masing-masing. Dalam Undang-Undang Nomor 3Tahun 2002 tentang Pertahanan Negara pasal 9 ayat 1 disebutkan bahwa "Setiap warga negara berhak dan wajib ikut serta dalam upaya bela negara yang diwujudkan dalam penyelenggaraan pertahanan negara". Bela negara dapat dibedakan secara fisik maupun non fisik. Secara fisik dapat disamakan dengan bela negara dalam arti militer. Sedangkan bela negara secara non fisik dapat didefinisikan sebagai segala upaya untuk mempertahankan Negara Kesatuan Republik Indonesia dengan cara meningkatkan kesadaran berbangsa dan bernegara, menanamkan kecintaan terhadap tanah air serta berperan aktif dalam memajukan bangsa dan negara, termasuk penanggulangan ancaman. Bela negara demikian dapat dipersamakan dengan bela negara secara nonmiliter (Wijianto, 2019).

\section{Analisis Data}

Berdasarkan hasil kuesioner diperoleh data yang disusun dalam Tabel 1 yang berkaitan dengan frekuensi penelusuran dan penyebaran informasi oleh responden penelitian.

Tabel 1 menunjukkan bahwa responden cukup aktif dalam mengikuti perkembangan informasi setiap hari. Hal ini menunjukkan bahwa responden selalu meng-update informasi. Responden selalu berusaha mencari informasi terbaru. Pencarian informasi setiap hari sudah menjadi sebuah kebutuhan bagi responden. Media internet sering digunakan untuk mencari informasi karena mudah aksesnya, ringan biayanya dan praktis. Seseorang tidak perlu berkemampuan khusus untuk memperoleh informasi tersebut, tetapi hanya memerlukan peralatan media

Tabel 1

Frekuensi Penelusuran dan Penyebaran Informasi yang dilakukan oleh responden.

\begin{tabular}{|c|c|c|c|}
\hline Pertanyaan & Sering & Jarang & Tidak pernah \\
\hline 1. Apakah anda mengikuti perkembangan informasi setiap hari? & $90 \%$ & $9 \%$ & $1 \%$ \\
\hline 2. Apakah anda dalam keseharian menggunakan sosial media? & $97 \%$ & $3 \%$ & $0 \%$ \\
\hline 3. Apakah anda hanya menggunakan sosial media untuk mencari informasi? & $0 \%$ & $14 \%$ & $86 \%$ \\
\hline 4. Apakah anda menyimpan informasi yang diperoleh untuk anda sendiri? & $3 \%$ & $5 \%$ & $92 \%$ \\
\hline $\begin{array}{l}\text { 5. Apakah anda membagi informasi yang anda peroleh dengan teman-teman } \\
\text { atau relasi anda? }\end{array}$ & $87 \%$ & $5 \%$ & $8 \%$ \\
\hline $\begin{array}{l}\text { 6. Apakah anda melakukan penelusuran kebenaran informasi yang anda } \\
\text { peroleh? }\end{array}$ & $6 \%$ & $8 \%$ & $86 \%$ \\
\hline $\begin{array}{l}\text { 7. Apakah anda mengalami kesulitan dalam mengakses informasi yang } \\
\text { dibutuhkan? }\end{array}$ & $1 \%$ & $5 \%$ & $94 \%$ \\
\hline 8. Apakah sumber informasi yang anda peroleh melalui media cetak? & $1 \%$ & $4 \%$ & $95 \%$ \\
\hline 9. Apakah anda lebih banyak menggunakan sumber informasi secara online? & $97 \%$ & $2 \%$ & $1 \%$ \\
\hline $\begin{array}{l}\text { 10.Apakah anda melakukan penelusuran kebenaran informasi yang anda } \\
\text { dapatkan? }\end{array}$ & $23 \%$ & $30 \%$ & $47 \%$ \\
\hline $\begin{array}{l}\text { 11. Apakah anda melakukan pengecekan background pihak yang menjadi } \\
\text { sumber informasi? }\end{array}$ & $25 \%$ & $37 \%$ & $38 \%$ \\
\hline $\begin{array}{l}\text { 12.Apakah anda melakukan pengecekan kebenaran informasi terhadap sumber- } \\
\text { sumber lain yang lebih dapat dipercaya? }\end{array}$ & $27 \%$ & $32 \%$ & $41 \%$ \\
\hline 13.Apakah anda mencatat pihak-pihak yang sering menyebarkan berita hoaks? & $14 \%$ & $34 \%$ & $52 \%$ \\
\hline
\end{tabular}

Sumber: analisis data primer 2019 
komunikasi yang bisa support terhadap jenis informasi yang diinginkan. Akses informasi mudah didapat berasal berbagai sumber, baik sumber perorangan maupun sumber sebuah instansi pemerintah ataupun swasta.

Tidak semua sumber informasi tersebut dapat dipercaya memberikan informasi yang benar sesuai dengan kenyataan. Responden selalu mengikuti perkembangan informasi dan berusaha mencari informasi-informasi yang ada di sekitarnya. Namun kemudahan dalam penelusuran media internet tersebut belum diimbangi dalam hal penelusuran kebenaran informasi atau berita, sehingga validitas informasi tidak diketahui. Hanya sedikit para narasumber yang melakukan penelusuran informasi lanjut. Responden juga kesulitan dalam mengenali/mengidentifikasi kebenaran sebuah informasi. Selain kendala keterbatasan peralatan yang mereka miliki untuk mengidentifikasi kebenaran sebuah informasi, juga banyaknya pihak-pihak yang menyebarkan informasi tidak benar, sehingga kebenaran sebuah informasi menjadi tertutupi oleh informasi yang tidak benar.

Efek psikologis dari responden dipermainkan oleh informasi yang selalu ditampilkan setiap detik dan setiap hari, sehingga responden akan menganggap informasi tersebut benar karena banyak yang menyebarkannya. Dengan adanya internet hal ini mudah dilakukan dalam hitungan detik. Sebagian besar responden penelitian langsung membagikan informasi atau berita melalui komunitas atau grup. Mereka menganggap bahwa informasi yang mereka dapatkan juga harus diketahui oleh kawan-kawannya. Hal ini juga berhubungan dengan kebiasaan masyarakat Indonesia yang memiliki prinsip guyup dan memiliki rasa kekeluargaan yang besar.
Berdasarkan data yang dirilis Perserikatan Bangsa-bangsa, saat ini tercatat 3,9 miliar orang atau yang berarti lebih dari setengah populasi dunia telah menggunakan internet. Menurut data Komisi Telekomunikasi Internasional (International Telecommunication Union/ ITU) memprediksi hingga akhir 2018 terdapat 51,2 persen dari populasi dunia yang menggunakan internet. (anonim. 2020)

Angka ini merepresentasikan kemajuan penting secara global tentang penggunaan internet, semakin bertambah besar jumlah angka, maka semakin berkembang pula pertambahan pengguna internet secara global. Angka ini diperkirakan akan bertambah terus karena kemajuan teknologi, dengan berkembangnya kemajuan teknologi menyebabkan pengguna internet semakin meningkat, hal ini karena biaya komunikasi akan semakin terjangkau, karena apabila teknologi berkembang maka semakin cepat dalam mengakses informasi, dampaknya akan mengurangi waktu yang diperlukan untuk mencari atau mengakses suatu informasi, bertambahnya pengguna internet pada masyarakat dunia diharapkan juga meningkatkan ekonomi dunia serta membantu perkembangan bisnis, dahulu bisnis lebih banyak dilakukan secara offline dengan cara membuka toko secara fisik yang memerlukan biaya cukup besar untuk operasional.

Catatan Komisi Telekomunikasi Internasional (International Telecommunication Union/ ITU menunjukkan pertumbuhan pengguna internet tertinggi berasal dari Negara-negara Afrika. Di Benua Afrika tercatat pertumbuhan pengguna internet mencapai 24,4 persen dari 2,1 persen pada periode yang sama setahun silam. Pertumbuhan internet di negara-negara berkembang juga mencatat 
Abdul Haris Subarjo, Wita Setianingsih -- Literasi Berita Hoaxs Di Internet Dan Implikasinya Terhadap Ketahanan Pribadi Mahasiswa

(Studi Tentang Penggunaan Media Sosial Pada Mahasiswa STT Adisutjipto Yogyakarta)

pertumbuhan pengguna secara signifikan. Dibandingkan 13 tahun silam yang hanya sebesar 7,7 persen, kini ada 45,3 persen orang di negara berkembang menjadi pengguna internet. (anonim. 2020)

Apabila dihubungkan dengan data hasil penelitian responden sering menggunakan intenet untuk mencari informasi, internet sudah menjadi bagian kehidupan mereka. Responden tidak menemui kesulitan pada saat mengoperasikan internet, mereka cukup familier dalam mengoperasikan perangkat internet. Hampir setiap waktu responden memanfaatkan internet untuk mencari informasi, mengerjakan tugas-tugas kuliah serta berhubungan dengan kawan-kawannya dan keluarganya melalui sarana sosial media facebook, intagram, tweeter, atau media sosial yang lain. Pada saat mengerjakan tugas responden oleh dosen diminta mengirimkan hasil tugasnya melalui email serta menelusuri literature-literatur/jurnal ilmiah dengan sarana internet. Hal ini menandakan responden cukup aktif dan terbiasa menggunakan perangkat internet.

Responden penelitian biasanya menggunakan perangkat komputer/laptop yang terhubung dengan wifi kampus atau dengan menggunakan paket data. Selain menggunakan laptop/perangkat komputer, responden juga menggunakan handphone yang terhubung dengan jaringan wifi atau paket data. Namun responden lebih sering memanfaatkan sarana handphone untuk bersosial media dengan kawan-kawannya maupun keluarganya.

Berdasarkan Grafik 1, rata-rata jumlah pengguna mengalami peningkatan apabila kita bandingkan data survei pada tahun 2017 dengan data survei tahun 2018. Pada survei Asosiasi Penyelenggara Jasa Internet Indonesia pada tahun 2017 jumlah pengguna internet $54,68 \%$ pada tahun 2018 terjadi kenaikan 64,80\%. Terjadi kenaikan lebih dari $10 \%$ pengguna internet data pengguna internet tahun 2017 bila dibandingkan dengan tahun 2018.

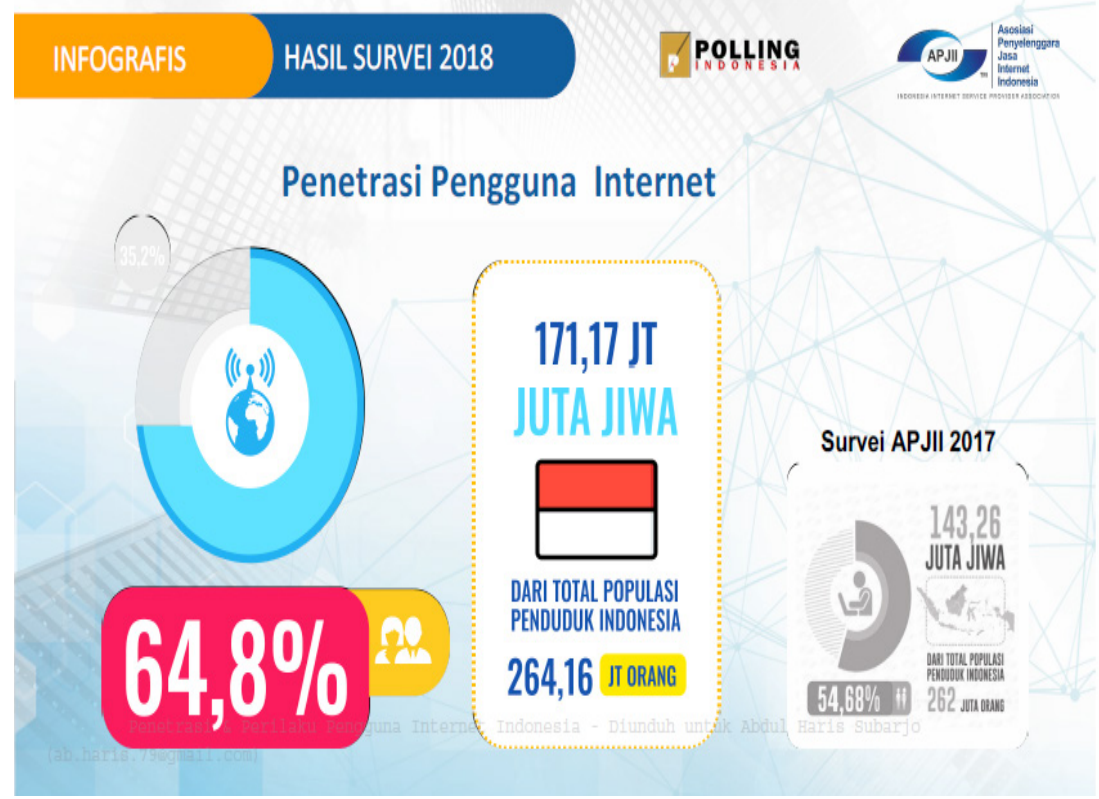

Sumber: Asosiasi Penyelenggara Jasa Internet, 2018 
Pertumbuhan pengguna internet di negara-negara maju tercatat pertumbuhan paling lambat dan stagnan dalam hal peningkatan pengguna internet, tercatat dari negara-negara maju hanya tumbuh 51,3 persen menjadi 80,9 persen populasi pada 2005 silam. (anonim. 2020)

Hal ini dapat disebabkan karena sarana prasarana untuk menggunakan internet di negara berkembang mengalami perbaikan dan pertambahan fasilitas. Selain itu di negara berkembang internet baru menjadi sebuah tren serta kebutuhan karena dirasakan manfaatnya serta kepraktisannya.

Situs-situs jejaring sosial, seperti Facebook, YouTube, Twitter, sebagai media sosial memanjakan penggunanya dengan kemudahan-kemudahannya agar mudah berpartisipasi, berbagi informasi, berbagi pesan serta menyatakan pendapat. Blog maupun jejaring sosial adalah bentuk media sosial yang paling umum digunakan oleh masyarakat di seluruh dunia. Sejak awal memang kemunculan situs jejaring sosial ini diawali dari adanya inisiatif dan keinginan dari pembuatnya/ inisiatornya untuk menghubungkan orang dari seluruh belahan dunia, hal ini dapat membuat dunia tanpa batas. (Watkins, S.Craig dalam Achmadudin Rajab. 2017)

Responden penelitian ini sering memanfaatkan media sosial seperti Facebook, YouTube, Twitter untuk berhubungan dengan kawan-kawannnya serta keluarganya. Hampir setiap waktu responden melakukan komunikasi menggunakan media sosial. Media sosial telah menjadi bagian kehidupan mereka seharihari. Di handphone serta laptop responden terdapat menu download media sosial. Media sosial di internet bagi responden telah menjadi kebutuhan yang utama. Umumnya para responden tidak mengalami kesulitan dalam mengoperasikan media sosial di internet.

Grafik 2

Penetrasi Internet Indonesia Berdasarkan Urban dan Rural

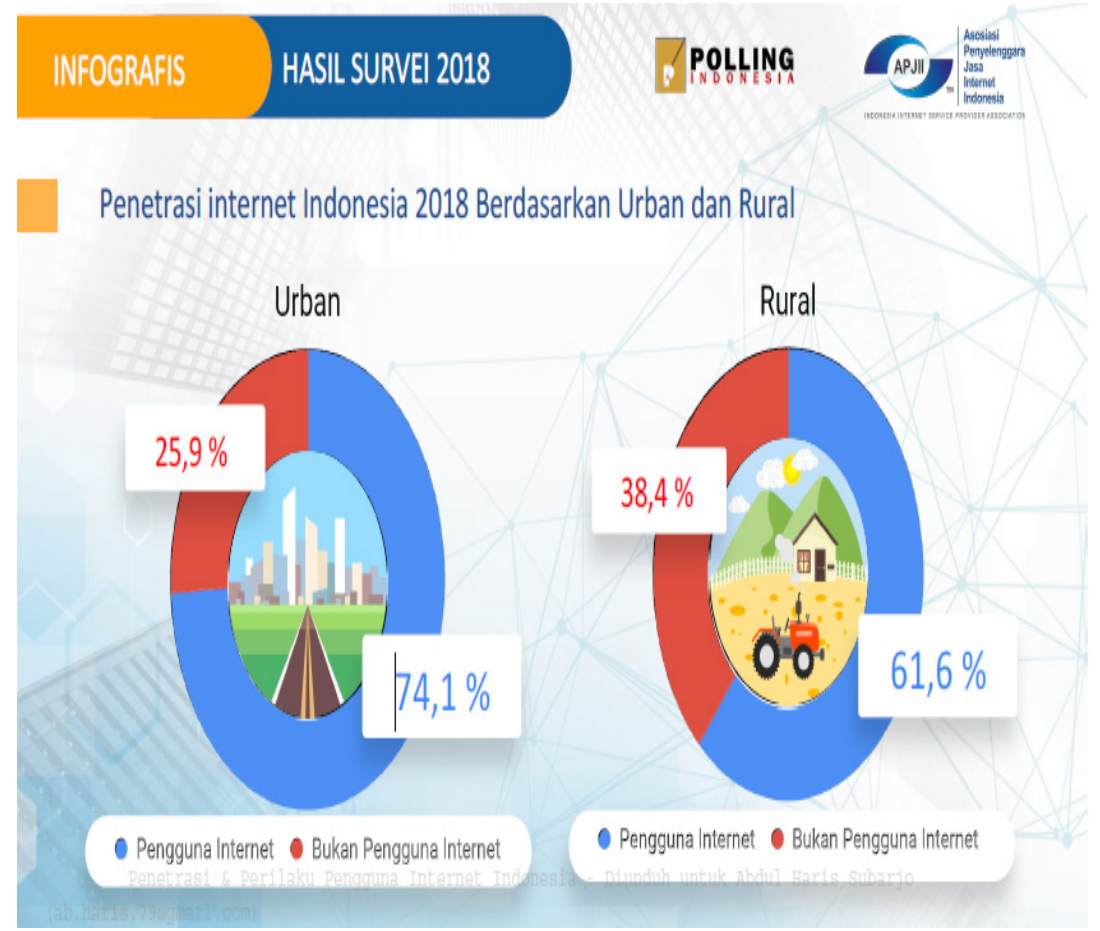

Sumber: Asosiasi Penyelenggara Jasa Internet, 2018 
Abdul Haris Subarjo, Wita Setianingsih -- Literasi Berita Hoaxs Di Internet Dan Implikasinya Terhadap Ketahanan Pribadi Mahasiswa

(Studi Tentang Penggunaan Media Sosial Pada Mahasiswa STT Adisutjipto Yogyakarta)

Berdasarkan hasil survei Asosiasi Penyelenggara Jasa Internet Indonesia pengguna (Grafik 2), internet lebih banyak di daerah urban dibandingkan daerah rural. Hal ini karena sarana prasarana dan jaringan internet lebih mudah diakses di wilayah urban. Di daerah urban banyak terdapat perkantoran modern, kampus, pusat perbelanjaan serta kantor-kantor pemerintah, sedangkan daerah rural lebih banyak terdapat kawasan pertanian serta peternakan sehingga pengguna internet lebih sedikit apabila dibandingkan daerah urban. Selain itu penduduk di kawasan urban lebih membutuhkan akses informasi yang cepat.

Responden dalam penelitian ini sebagian besar bertempat tinggal di daerah urban. Hal ini bisa dilihat dari posisi kampus STTA yang terletak di pinggiran kota Yogyakarta, sehingga 96\% responden tinggal di sekitar kampus STTA. Sekitar 4\% di antaranya bertempat tinggal agak jauh dari kampus STTA, namun masih di kawasan urban di sekitar kota Yogyakarta.

Grafik 3 menunjukkan bahwa pengguna internet terbanyak pada usia 15-19 tahun yaitu 91\%. Sedangkan pada usia 10-44 tahun ratarata pengguna internet dibandingkan bukan pengguna internet lebih banyak penguna internet. Sehingga apabila kita melihat data ini diperlukan kemampuan literasi bagi pengguna internet, usia 10-44 tahun dibandingkan dengan usia diatas 50 tahun. Usia 50 tahun pada umumnya memiliki kelebihan dalam hal kematangan emosi dalam bertindak lebih. Setelah rentang usia 20-24 tahun berdasarkan grafik hasil survei Asosiasi Penyelenggara Jasa Internet Indonesia terlihat

Grafik 3

Penetrasi Pengguna Internet 2018 Berdasarkan Umur

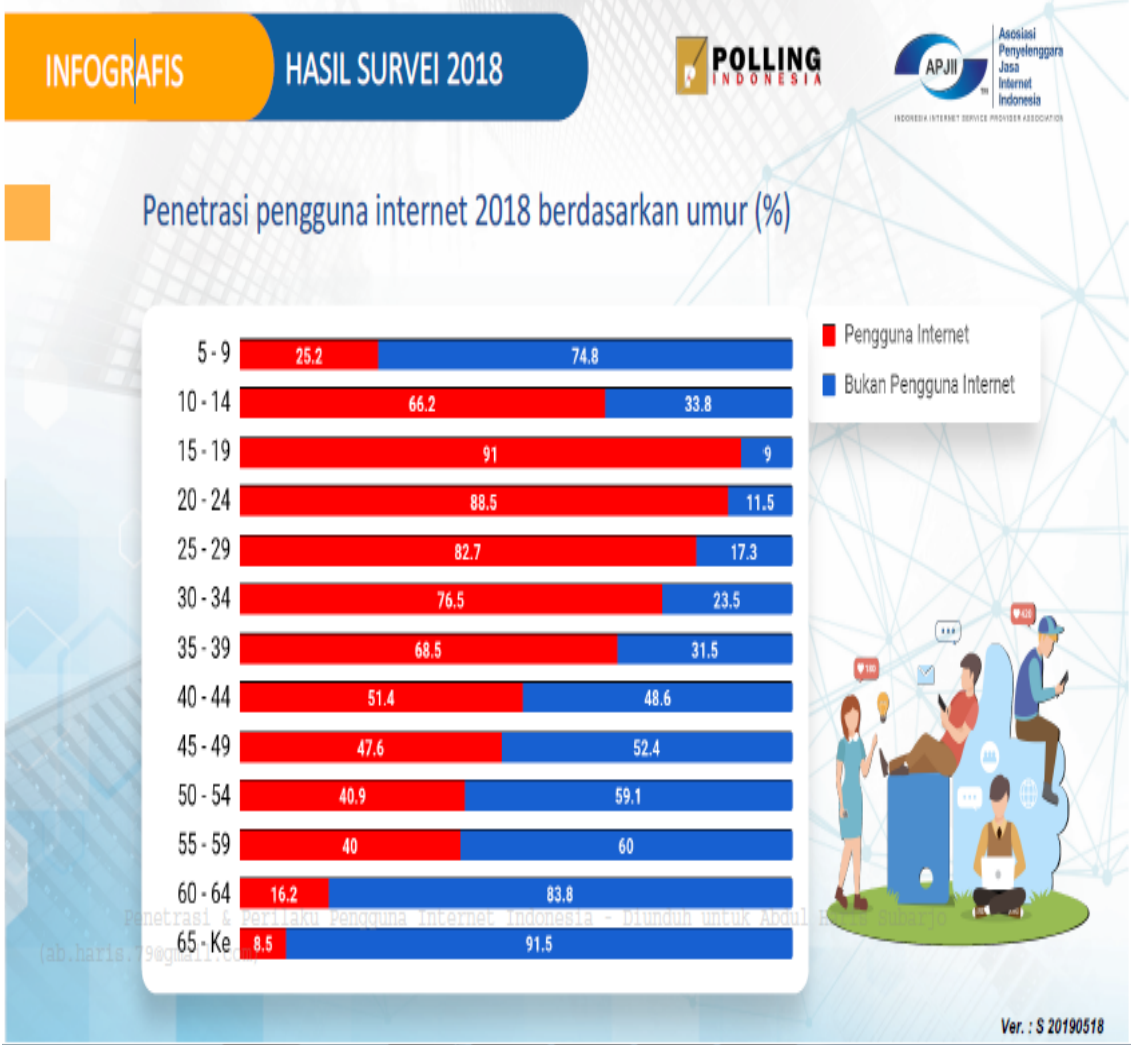

Sumber: Asosiasi Penyelenggara Jasa Internet, 2018 
kecenderungan penurunan angka persentase pengguna internet.

Berdasarkan data responden keseluruhan responden berusia 18-20 tahun. Apabila melihat data tabel maka berarti termasuk diantara pengguna internet terbanyak dari data pengguna internet hasil survei Asosiasi Penyelenggara Jasa Internet Indonesia. Berdasarkan survei Asosiasi Penyelenggara Jasa Internet Indonesia usia terbanyak pengguna internet adalah pada rentang usia 1519 tahun berjumlah $91 \%$ serta terbanyak kedua adalah rentang usia 20-24 tahun. Pada usia tersebut kematangan emosi biasanya belum terlalu terbentuk sehingga membutuhkan pengetahuan dalam hal literasi informasi, agar responden dapat memilah informasi yang baik bagi dirinya, serta dapat mengidentifikasi berita/informasi yang responden peroleh adalah termasuk kategori informasi hoaks atau informasi dari kejadian sebenarnya.

Grafik 4 menunjukkan bahwa pengguna internet rata-rata memiliki pendidikan tinggi, rata-rata memiliki pendidikan diatas smp, bahkan untuk pengguna internet yang tamat S-3 cukup banyak. Hal ini karena untuk pengoperasian internet membutuhkan kemampuan dalam pengoperasian teknologi. Berdasarkan data pada Grafik 4 bisa disimpulkan bahwa rata-rata pengguna internet

Grafik 4

Penetrasi Pengguna Internet Berdasarkan Tingkat Pendidikan

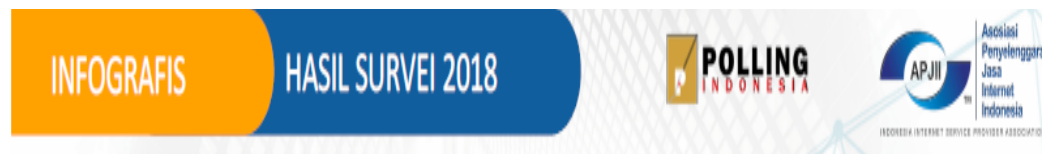

Penetrasi Pengguna Internet Berdasarkan Tingkat Pendidikan

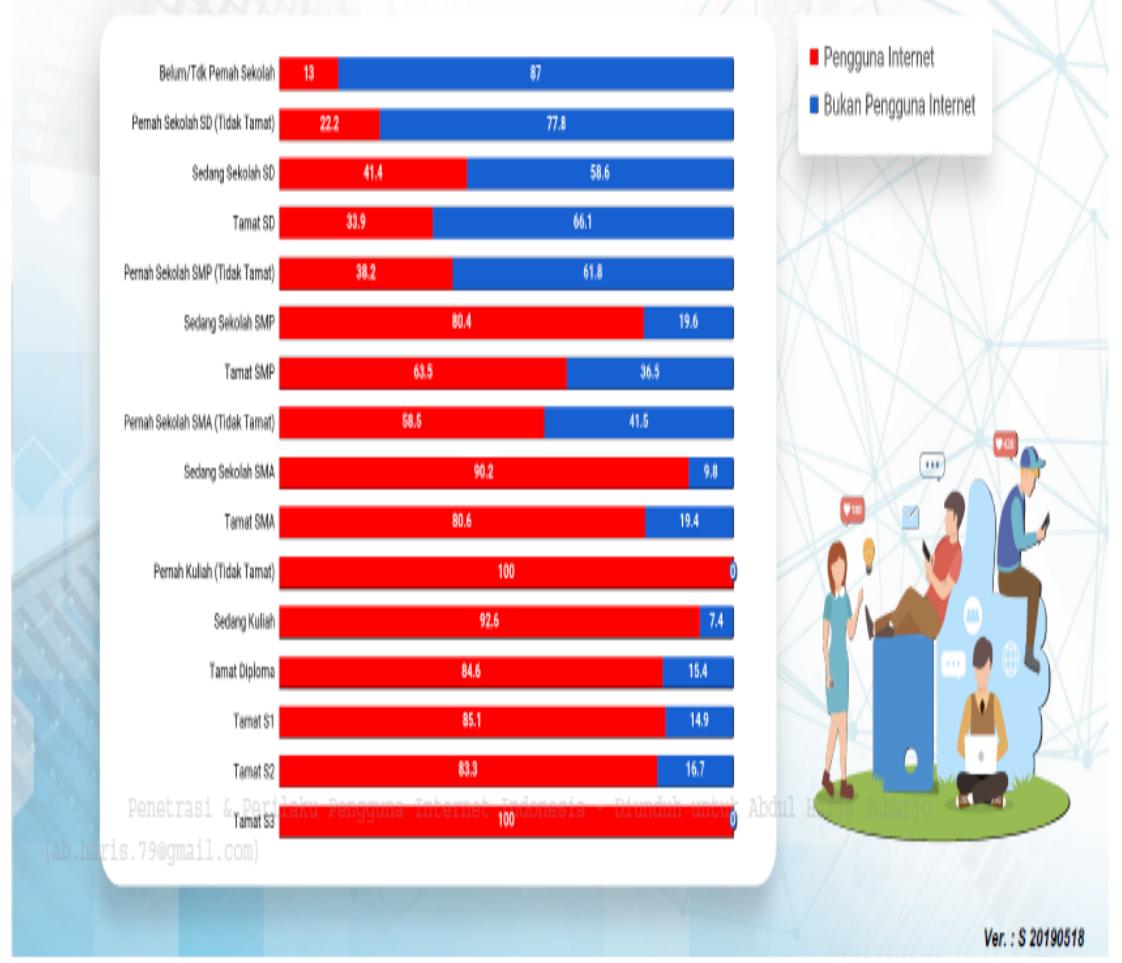

Sumber: Asosiasi Penyelenggara Jasa Internet, 2018 
Abdul Haris Subarjo, Wita Setianingsih -- Literasi Berita Hoaxs Di Internet Dan Implikasinya Terhadap Ketahanan Pribadi Mahasiswa (Studi Tentang Penggunaan Media Sosial Pada Mahasiswa STT Adisutjipto Yogyakarta)

Grafik 5

Alasan Paling Utama Anda Dalam Menggunakan Internet

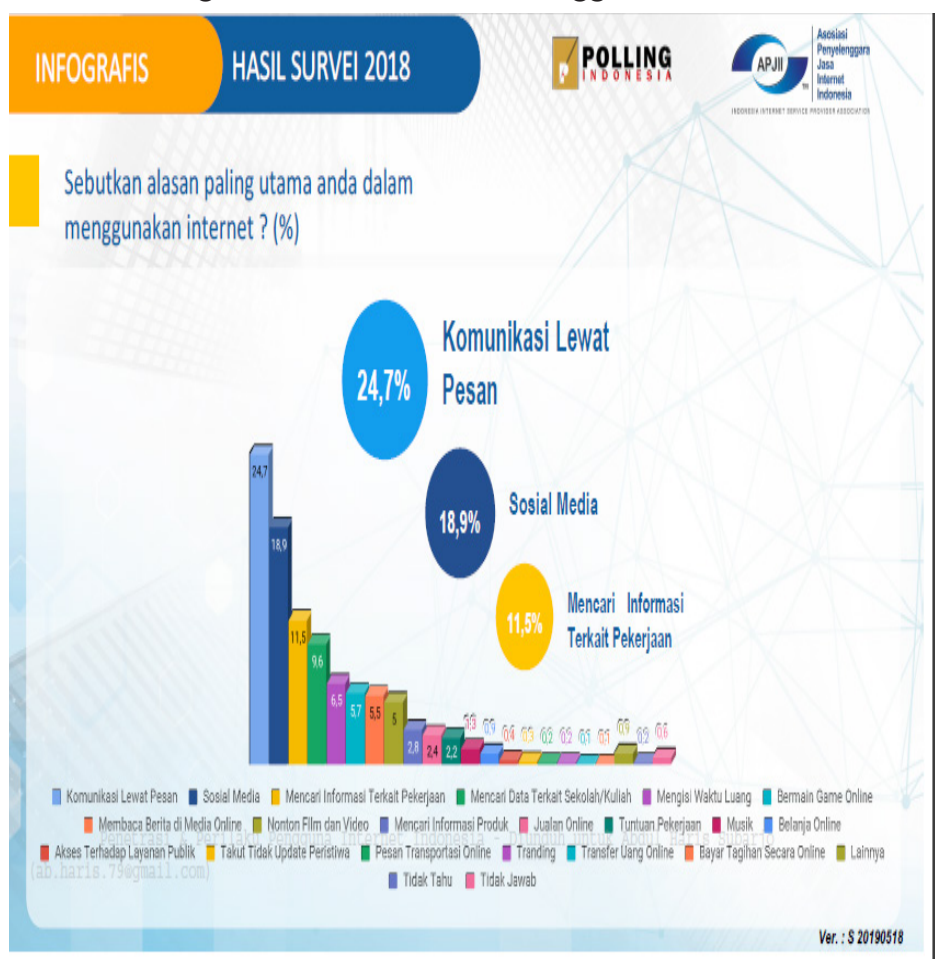

Sumber: Asosiasi Penyelenggara Jasa Internet, 2018

yang memiliki kemampuan literasi yang bagus ialah mereka yang memiliki tingkat pendidikan yang cukup. Responden penelitian ini ialah kalangan mahasiswa yang dalam Grafik 4 hasil survei dari Asosiasi Penyelenggara Jasa Internet Indonesia termasuk dalam kelompok "sedang kuliah".

Berdasarkan data diatas terdapat $18,9 \%$ alasan utama pengguna internet yang berhubungan dengan relasi / kawannya dengan menggunakan media sosial.

Data pada Grafik 6 menunjukkan bahwa jumlah pengguna internet dengan alasan kedua untuk bersosial media menempati urutan terbesar sekitar 19,1\%. Lebih banyak dibandingkan alasan utama menggunakan internet dengan tujuan untuk bersosial media. Namun apabila kita membandingkan data tujuan utama dan tujuan kedua, pada tujuan utama kita lihat pengguna internet untuk tujuan komunikasi dengan teman dan relasi.

Berdasarkan data Grafik 7, pengguna media sosial facebook tercatat yang paling banyak, yakni sebesar 50,7\% pengguna dibanding pengguna media sosial instagram dan youtube. Sedangkan responden penelitian ini menyebutkan bahwa media sosial yang paling sering diakses adalah facebook sebesar $48 \%$, sedangkan media sosial lainnya seperti instagram, tweeter berada di bawahnya.

Berdasarkan data dari Balitbang SDM Kemkominfo, konten yang bernuansa pornografi berada di ranking pertama (74,34\%), kemudian diikuti konten SARA $(45,11 \%)$, dan konten lain. Masih tingginya konten pornografi di media daring bisa jadi karena pornografi sengaja diproduksi produk bernilai tinggi dalam industri media global. 
Grafik 6

Sebutkan Alasan Kedua Anda Dalam Menggunakan nternet

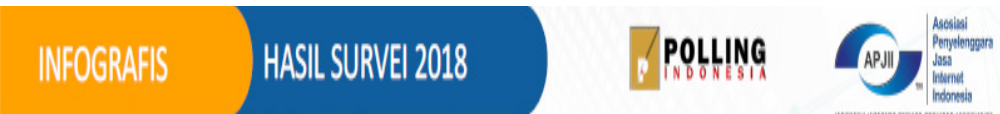

Sebutkan alasan kedua anda dalam menggunakan Internet? (\%)

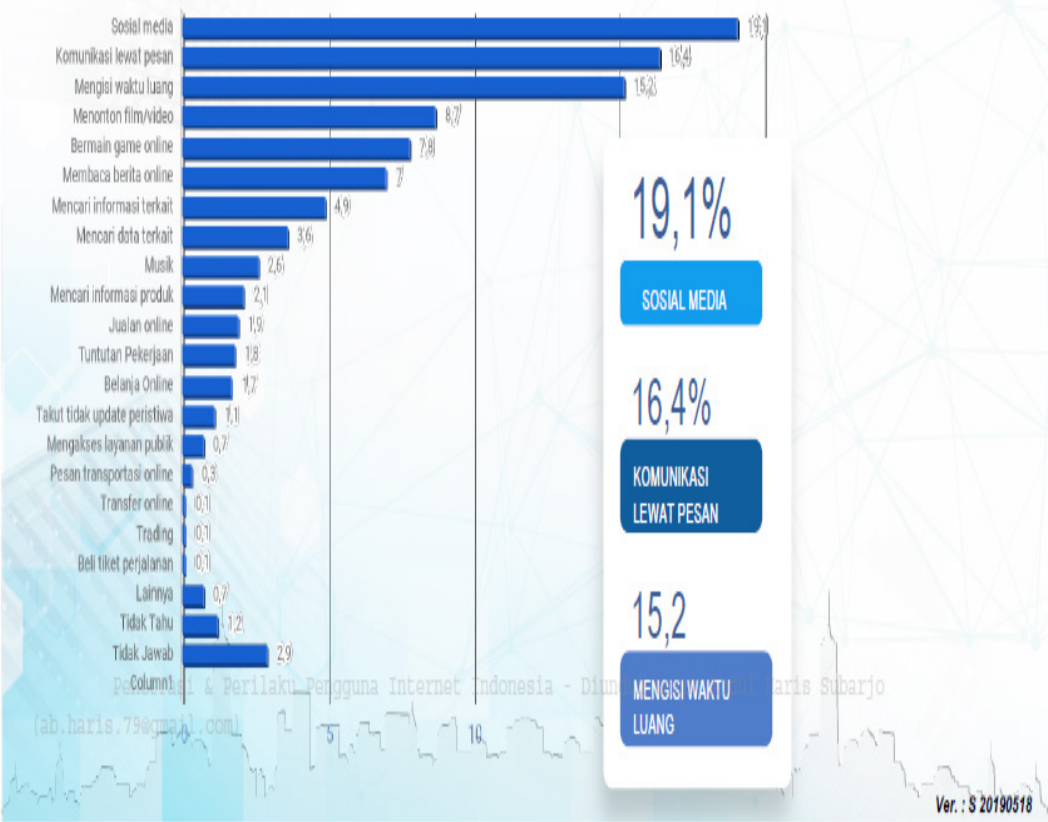

Sumber: Asosiasi Penyelenggara Jasa Internet, 2018

Grafik 7

Sebutkan Konten Internet (Media Sosial) Apa Yang Paling Sering Anda Kunjungi

INFOGRAFIS HASILSURVEI 2018 PNOLLING

Sebutkan konten internet (Media Sosial) apa yang paling sering Anda kunjungi?
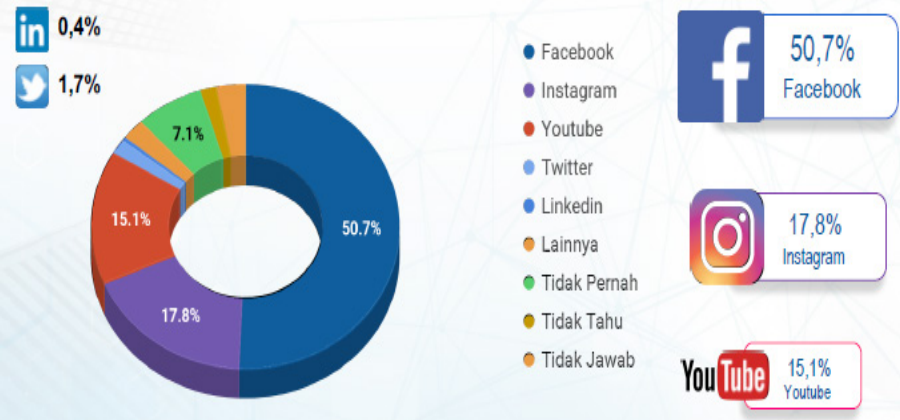

Ver: : 20190518

Sumber: Asosiasi Penyelenggara Jasa Internet, 2018 
Abdul Haris Subarjo, Wita Setianingsih -- Literasi Berita Hoaxs Di Internet Dan Implikasinya Terhadap Ketahanan Pribadi Mahasiswa (Studi Tentang Penggunaan Media Sosial Pada Mahasiswa STT Adisutjipto Yogyakarta)

Grafik 8

Jumlah konten Negatif di Media Online

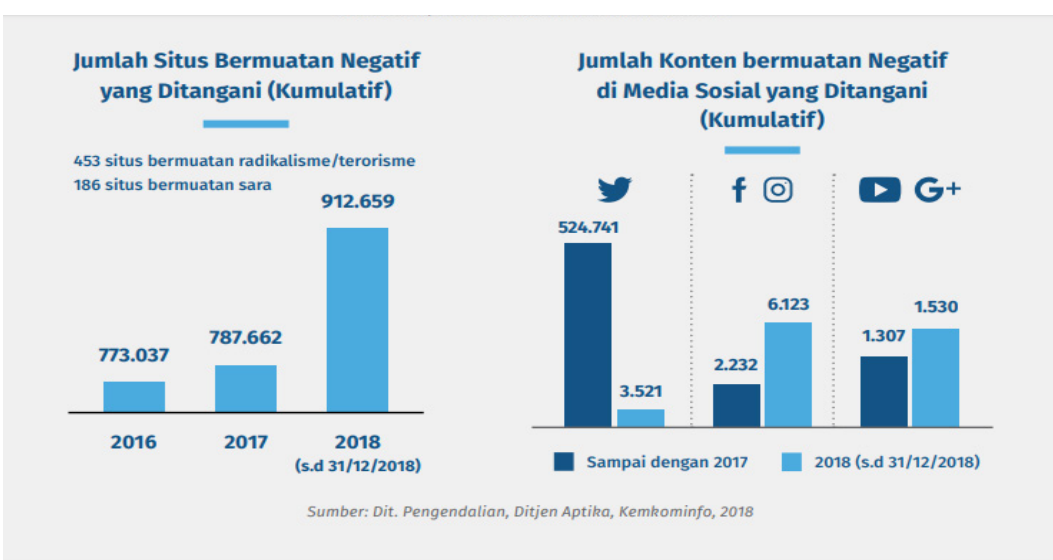

Sumber: Astri Nur Afidah dan Marshel Doom, Laporan Tahunan 2018 Kementrian Komunikasi dan Informatika Tahun 2018

Sementara konten SARA (suku, agama dan ras) menempati urutan kedua lantaran dimanfaatkan sebagai materi kampanye politik pada pilkada serentak (27/6/2018), dan menjelang kampanye pemilihan presiden dan pemilihan legislatif (17/4/2019) mendatang.

Data Kemenkominfo menyebutkan bahwa ada sekitar 800.000 situs di Indonesia yang telah terindikasi sebagai penyebar informasi palsu. Internet telah salah dimanfaatkan oknum tertentu untuk keuntungan pribadi dan kelompoknya dengan cara menyebarkan konten-konten negatif yang menimbulkan keresahan dan saling mencurigai di masyarakat. (Ayu Yuliani, 2017)

Pada kasus hoaxs di papua beberapa bulan yang lalu dilakukan pemberlakuan pembatasan akses internet di Papua dan Papua Barat, mengingat sangat besarnya sebaran konten berita bohong atau hoaxs soal kasus Papua yang sudah mencapai 52 ribu konten. Hal ini dilakukan oleh aparat kepolisian bersama Kementrian Komunikasi dan Informatika pasca aksi unjuk rasa massa yang berujung anarkis di Jayapura, Kamis, 29 Agustus 2019. Karena penyebaran hoaxs terpantau terus meningkat taja, maka pembatasan akses internet memang diperlukan agar berita bohong tersebut tidak menyebar ke masyarakat. Sementara itu, pada waktu yang sama di tempat berbeda, Kementerian Komunikasi dan Informatika menginformasikan bahwa mereka telah mengidentifikasi ratusan ribu Uniform Resource Locator (URL) hoaxs terkait Papua. Ada lebih dari 500 ribu URL hoax ditemukan. Jadi jumlah URL yang digunakan untuk menyebarkan hoax. Isi hoax tersebut menurut Rudiantara adalah pesan yang mengandung narasi adu domba serta informasi palsu yang dikhawatirkan bisa memperburuk keadaan dan stabilitas keamanan. Jumlah 500 ribu URL hoaxs ini meningkat terus, karena sebelumnya Kemenkominfo sudah mengantongi data 230 ribu URL hoax. Selain itu penyebaran hoax terkait situasi di Papua dan Papua Barat masih ramai melalui media sosial Twitter. Oleh karena Kementrian Komunikasi dan Infomatika masih terus memberlakukan pembatasan akses internet di Papua dan Papua Barat 
guna meredam konflik yang lebih luas dan lebih parah. (Miechell Octovy Koagouw, 2019).

Kebebasan berpendapat dan bersikap termasuk dalam media sosial sangat dijamin oleh konstitusi dan undang-undang. Di dalam undangundang setiap orang tanpa memandang suku, ras, agama, dan golongan diberikan kebebasan dan dijamin oleh negara manapun untuk berserikat dan berkumpul serta mengemukakan pendapatnya. Namun terkadang hal ini pula yang dimanfaatkan oleh oknum-oknum tertentu untuk kepentingan politik, kepentingan pribadi, dan kepentingan golongannya yang implikasinya dapat membawa dampak negatif bagi rakyat dan bangsa Indonesia. Kegaduhan-kegaduhan ini pula dapat memberikan dampak panjang jika Pemerintah tidak memiliki solusi yang pasti yakni dapat mengancam keutuhan Negara Kesatuan Republik Indonesia. (Achmadudin Rajab, 2017)

Ketika para pengguna media baik langsung atau pengguna tidak langsung baik sengaja maupun tidak sengaja dengan niat menyebarkan isu bermuatan suku, agama, ras, dan antargolongan (SARA), maka isu tersebut dikhawatirkan akan memecah belah persatuan dan kesatuan bangsa apabila isu tersebut memiliki potensi sebagai penyebab konflik. (Achmadudin Rajab, 2017)

Sebagaimana kita ketahui media sosial saat ini menawarkan banyak kemudahankemudahan serta kepraktisan maka dengan kemudahan-kemudahan dan kepraktisan tersebut effect dari globalisasi akan masuk dengan mudahnya tanpa melalui saringan yang cukup ketat dan panjang melalui kemajuan media sosial ini. Efek globalisasi akan masuk dan meluas menjadi penyebab pengaruh di suatu negara tertentu. Proses globalisasi mengandung implikasi bahwa suatu aktifitas yang sebelumnya terbatas jangkauannya secara nasional dan cuma dapat diakses secara lokal/nasional, secara bertahap berkembang menjadi tidak terbatas pada suatu negara dan dapat cepat meluas secara regional maupun jangkuan yang lebih jauh.

Untuk menggali data lebih dalam dilakukan wawancara apakah tidak terdapat kekhawatiran bila informasi atau berita tersebut tidak benar, responden menjawab "biasanya apabila terdapat ketidakbenaran informasi akan ada pemberitahuan/konfirmasi dari anggota grup yang lain atau dari informasi dari sumber-sumber yang lebih dapat dipercaya". Misal informasi mengenai terjadinya tsunami di suatu daerah, setelah informasi ini menyebar luas di masyarakat dan menjadi viral biasanya pihak yang berkompeten seperti Badan Meteorologi Klimatologi Geofisika akan memberikan konfirmasi melalui media sosial, media cetak, televisi serta radio. Sehingga responden beranggapan tidak perlu takut memberikan sebuah informasi nanti pasti ada informasi dari pemerintah.

Apabila kita melihat beberapa definisi literasi yaitu sebagai suatu kemampuan mengetahui pengetahuan yang meliputi keterampilan mengenai bagaimana berfikir dengan menggunakan sumber-sumber pengetahuan, yang kemudian akan diolah atau implementasikan maka kasus penyebaran berita hoaks pada kasus di Papua apabila kita memiliki kemampuan literasi yang baik maka tidak akan dapat mengancam ketahanan wilayah dan pada skala yang lebih besar mengancam ketahanan nasional. karena kasus ini tidak hanya menyebabkan konflik di papua saja, namun juga menimbulkan kekhawatiran konflik di beberapa daerah yang bernuansa suku, agama, ras dan antar golongan. Hal ini terlihat dari berita konflik yang terjadi 
Abdul Haris Subarjo, Wita Setianingsih -- Literasi Berita Hoaxs Di Internet Dan Implikasinya Terhadap Ketahanan Pribadi Mahasiswa

(Studi Tentang Penggunaan Media Sosial Pada Mahasiswa STT Adisutjipto Yogyakarta)

di Wamena, Kabupaten Jayawijaya, dan Waena, Kota Jayapura. Kelambanan dalam menyelesaikan konflik berpotensi membuat peristiwa serupa meluas ke berbagai penjuru Papua. Kerusuhan terjadi di Wamena pada Senin pekan lalu, 23 September 2019. Massa diduga tersulut berita bohong soal ujaran rasial seorang guru kepada seorang pelajar SMP di sana. Mereka lalu membakar pertokoan dan kantor pemerintah. Hingga Jumat lalu, tercatat 33 orang tewas, 28 di antaranya adalah pendatang. Lebih dari 7.200 orang dievakuasi dan sekitar 7.500 pendatang masih mengungsi akibat konflik horizontal di Wamena. Papua tak henti dilanda konflik berdarah. Setelah ujaran rasial dan persekusi terhadap mahasiswa asal Papua di Surabaya, Jawa Timur, menjelang peringatan hari kemerdekaan Indonesia, kericuhan menyebar ke berbagai penjuru Papua (anonim, 2019).

Karakteristik responden mewakili dari komunitas orang-orang yang memiliki pendidikan tinggi. Rata-rata responden telah lulus sekolah menengah atas, sehingga dengan karakteristik responden ini diharapkan responden dapat membaca sebuah informasi dan mengerti arti atau makna sebuah informasi yang diperolehnya. Dengan pendidikan tinggi tersebut diharapkan lebih berhatihati dalam bersikap dan bertindak, karena mereka lebih mengerti tentang dampak dari sebuah informasi, namun untuk melakukan literasi internet para responden memerlukan kemampuan lebih, agar mereka dapat membedakan kebenaran berita yang mereka dapatkan dan lebih berhati-hati dalam bertindak. Hal ini juga dipengaruhi oleh adanya undang-undang Informasi Teknologi Elektronik, dengan adanya undang-undang ini diharapkan dapat mencegah dampak negatif dari sebuah informasi.
Para responden hanya sedikit yang melakukan pencatatan pihak-pihak yang sering menyebarkan berita hoaxs. Sehingga mereka tidak bisa cepat mengambil kesimpulan, bahwa perlu lebih berhati-hati apabila mendapatkan kiriman informasi dari pihak tersebut. Sebagian besar responden hanya sedikit yang mencari informasi pembanding ke pihak lain. Sehingga dapat kita ketahui bahwa responden tidak mengetahui tentang kebenaran berita/informasi. Berdasarkan hasil penelitian dapat diperoleh informasi tentang pentingnya menggalakkan literasi informasi pada masyarakat terutama masyarakat di kampus, karena informasi yang tidak benar dapat berpotensi menimbulkan keresahan dimasyarakat. Dan ketidakbenaran informasi dapat mengancam persatuan dan ketahanan nasional. ketidakbenaran informasi dapat menimbulkan keresahan dimasyarakat. Sulit membedakan bahwa informasi tersebut benar atau hanya sebuah hoaxs. Masyarakat cenderung lebih percaya dengan kecepatan penyampaian informasi dari pada kebenaran informasi. Informasi awal yang mereka dapatkan lebih dipercaya dari pada informasi setelahnya. Dengan ketidak tahuan mereka mengenai berita hoaxs maka dapat berpengaruh terhadap Ketahanan nasional. ketahanan nasional dapat terpengaruh apabila berita hoaks tersebut menjadi pemicu tindakan-tindakan anarkisme, apalagi jika berita-berita tersebut disebarkan terus menerus dan oleh pelaku yang banyak. Hal ini menyebabkan responden merasa bahwa berita tersebut benar, karena tidak hanya mendapatkan informasi dari satu pihak saja dan berita tersebut di publish secara terus menerus.

\section{Identifikasi Berita Hoaxs}

Berita Hoaxs terkadang susah untuk diidentifikasi, masyarakat awam yang tidak 
memiliki kemampuan khususnya dibidang teknologi informasi sulit membedakan antara berita hoaxs dan berita yang sebenarnya, hal ini seperti yang dialami oleh responden penelitian. Membutuhkan kemampuan literasi media dan teknologi informasi bagi masyarakat untuk mengenali berita yang diterimanya hoaxs atau berita sebenarnya.

Berita hoaxs kadangkala menggunakan judul sensasional yang provokatif, hal ini bertujuan untuk memancing pembaca agar lebih tersentuh emosinya misalnya dengan langsung menudingkan jari ke pihak tertentu. Isi beritanya pun kadang diambil dari berita media resmi yang memiliki ijin dari pemerintah hanya saja kontennya diubahubah agar menimbulkan persepsi sesuai yang dikehendaki sang pembuat hoaxs (Yunita, 2017).

Oleh karena itu, apabila kita menjumpai berita-berita dengan judul provokatif, sebaiknya pembaca mencari referensi lain berupa berita serupa dari situs online resmi, kemudian setelah itu bandingkan isinya, apakah sama dengan berita yang dicurigai hoaxs atau berbeda isinya. Dengan demikian, setidaknya sebagai pembaca bisa mendapatkan kesimpulan yang lebih berimbang dan tidak langsung emosional dalam menanggapi sebuah isi berita dan tidak langsung mengambil uatu kesimpulan tanpa mengetahui berita yang sebenarnya.

Cara mengidentifikasi sebuah berita termasuk hoaxs atau tidak juga dapat dilakukan pada informasi-informasi yang kita peroleh dari website atau mencantumkan link, kita dapat cermati alamat URL situs yang dimaksud. Apabila berita-berita tersebut berasal dari situs-situs yang belum terverifikasi sebagai institusi pers resmi yang memiliki ijin dari pemerintah, misalnya menggunakan alamat domain blog, maka informasinya kemungkinan meragukan. Memperhatikan dari mana asal berita yang kita peroleh berasal dan siapa sumber informasinya? Apakah dari institusi resmi pemerintah atau bukan? Sumber berita sebaiknya berimbang, jangan hanya dari dari satu sumber saja, sebaiknya lebih dari satu sumber (Yunita, 2017).

Menurut Ketua Masyarakat Indonesia Anti Hoaks Septiaji Eko Nugroho dalam Yunita (2017) terdapat lima langkah-langkah sederhana untuk dapat membantu dalam mengidentifikasi berita yang diterima hoaxs atau berita sebenarnya, yaitu:

(1) Kita sebaiknya hati-hati dengan judu-judul artikel berita provokatif.

(2) Kita bisa mencermati alamat situs yang memposting berita provokatif tersebut.

(3) Kita sebaiknya periksa fakta

(4) Kita cek keaslian foto yang diposting.

(5) Ikut serta grup diskusi anti-hoaxs

Jenis-jenis Informasi Hoaxs menurut Rahadi, D.R. (2017):

Pertama, Fake news: Berita bohong: Berita yang berusaha menggantikan berita yang asli atau memalsukan sebuah berita.

Kedua, Clickbait: Tautan jebakan: Tautan diletakkan di dalam sebuah situs agar menarik orang masuk ke situs lainnya. Konten di dalam tautan sesuai fakta yang sebenarnya namun judulnya dibuat berlebihan.

\section{Ketiga, Confirmation bias}

Bias konfirmasi: Kecenderungan untuk menginterpretasikan kejadian yang baru terjadi sebaik bukti yang sudah ada.

Keempat, Misinformation: Informasi yang salah atau tidak akurat untuk menipu.

Kelima, Satire: Sebuah tulisan yang dibesar-besarkan untuk mengkomentari kejadian. 
Abdul Haris Subarjo, Wita Setianingsih -- Literasi Berita Hoaxs Di Internet Dan Implikasinya Terhadap Ketahanan Pribadi Mahasiswa (Studi Tentang Penggunaan Media Sosial Pada Mahasiswa STT Adisutjipto Yogyakarta)

Keenam, Post-truth: Pasca-kebenaran: Kejadian di mana emosi lebih berperan dari fakta untuk membentuk opini publik.

Hal lain yang perlu diamati adalah perbedaan antara berita yang dibuat berdasarkan fakta dan opini. Fakta adalah peristiwa yang terjadi dengan kesaksian dan bukti dan sesuai kenyataan yang terjadi, tidak ada yang dikurangi ataupun dilebihlebihkan, sementara opini adalah pendapat dan kesan dari penulis berita sehingga memiliki kecenderungan untuk bersifat subyektif sesuai dengan keinginan dan tujuan dari pembuat berita, agar nampak nyata biasanya ditambahkan bukti-bukti palsu.

Di era teknologi digital saat ini, bukan hanya konten berupa teks yang bisa dimanipulasi, melainkan juga konten lain berupa foto atau video. Ada kalanya pembuat berita palsu juga mengedit foto untuk memprovokasi pembaca. Cara untuk mengecek keaslian foto bisa dengan memanfaatkan mesin pencari Google, yakni dengan melakukan drag-and-drop ke kolom pencarian Google Images. Hasil pencarian akan menyajikan gambar-gambar serupa yang terdapat di internet sehingga bisa dibandingkan(Yunita, 2017).

Selain kita dapat mengidentifikasi sendiri dalam memilah sebuah informasi termasuk berita hoaxs atau berita dari kejadian yang sebenarnya dengan kemampuan literasi informasi yang kita miliki, kita juga dapat mengidentifikasi melalui grup-grup/forumforum anti hoaxs. Dengan melalui grup-grup anti hoaxs kita dapat mengidentifikasi berita hoaxs secara bersama-sama dan meningkatkan kemampuan literasi informasi kita.

Di Facebook terdapat sejumlah fanpage dan grup diskusi anti hoax, misalnya Forum Anti Fitnah, Hasut, dan Hoax (FAFHH), Fanpage
\& Group Indonesian Hoax Buster, Fanpage Indonesian Hoaxes, dan Grup Sekoci. Di grupgrup diskusi ini, netizen bisa ikut bertanya apakah suatu informasi merupakan hoax atau bukan, sekaligus melihat klarifikasi yang sudah diberikan oleh orang lain. Semua anggota bisa ikut berkontribusi sehingga grup berfungsi layaknya crowdsourcing yang memanfaatkan tenaga banyak orang (Yunita, 2017).

Setelah kita melakukan identifikasi agar berita hoaxs tersebut tidak menimbulkan dampak negatif bagi orang lain, masyarakat atau dampak lebih besar bagi ketahanan nasional Negara Indonesia sebaiknya kita melaporkan ke aparat yang berwenang.

Apabila menjumpai informasi hoaxs, lalu bagaimana cara untuk mencegah agar tidak tersebar. Pengguna internet bisa melaporkan hoaxs tersebut melalui sarana yang tersedia di masing-masing media sesuai dengan media sosial yang digunakan untuk menyebarkan berita hoaxs tersebut.

Untuk media sosial facebook, gunakan fitur Report Status dan kategorikan informasi hoax sebagai hatespeech/harrasment/rude/ threatening, atau kategori lain yang sesuai. Jika ada banyak aduan dari netizen, biasanya facebook akan menghapus status tersebut. Untuk google, bisa menggunakan fitur feedback untuk melaporkan situs dari hasil pencarian apabila mengandung informasi palsu. Twitter memiliki fitur Report Tweet untuk melaporkan twit yang negatif, demikian juga dengan Instagram (Yunita, 2017).

Apabila kita ingin melaporkan sebuah konten berita yang mengandung hoaxs atau tidak juga dapat melalui instansi resmi yaitu Kementrian Komunikasi dan Informasi dengan cara melayangkan e-mail ke alamat aduankonten@mail.kominfo.go.id. Nanti pihak Kementrian Komunikasi dan Informasi 
akan melakukan pengecekan lebih lanjut dan melakukan tindakan lebih lanjut sesuai ketentuan perundang-undangan.

Masyarakat Indonesia Anti Hoax juga menyediakan laman data.turnbackhoax.id untuk menampung aduan hoax dari netizen. TurnBackHoax sekaligus berfungsi sebagai database berisi referensi berita hoax. Menurut catatan Dewan Pers, di Indonesia terdapat sekitar 43.000 situs di Indonesia yang mengklaim sebagai portal berita. Dari jumlah tersebut, yang sudah terverifikasi sebagai situs berita resmi tak sampai 300. Artinya terdapat setidaknya puluhan ribu situs yang berpotensi menyebarkan berita palsu di internet yang mesti diwaspadai (Yunita, 2017).

\section{SIMPULAN}

Literasi suatu informasi diperlukan masyarakat dalam mendapatkan, memanfaatkan dan menyebar luaskan berbagai informasi yang diperoleh sehingga perlu pengecekan lebih lanjut dan pemeriksaan sumber informasi sebelum disebar luaskan. Penyebaran informasi yang benar serta santun dan tidak berpotensi konflik akan membuat penerima informasi menelaah dengan baik sehingga tidak terpancing untuk berbuat hal yang berdampak negatif. Literasi informasi di kalangan mahasiswa penting untuk memupuk ketahanan pribadi mereka. Tanpa literasi yang baik terutama berkaitan dengan berita hoak yang viral dapat merusak kepribadian dan menyesatkan pola piker dan sikap. Hal ini mudah menimbulkan keresahan masyarakat dan berpotensi menggangu ketahanan nasional. Pengguna internet dari semua background perlu memahami bahwa berita-berita di internet tidak semua benar. Tidak semua berita di internet dapat dipertanggungjawabkan oleh sumber informasi.
Berdasarkan hasil penelitian sebagian besar responden penelitian tidak melakukan literasi informasi. Hal ini terlihat dari data bahwa jumlah responen yang melakukan pengecekan sumber berita dan konten berita sangat kecil. Responden juga tidak melakukan pencatatan mengenai sumbersumber berita yang sering menyebarkan hoaxs di masyarakat. Hanya sedikit responden yang melakukan penelusuran berita yang berasal dari sumber berita resmi yang lebih dapat dipercaya keasliannya. Hal ini karena responden tidak memiliki kemampuan dalam mengidentifikasi mana yang termasuk berita hoaxs dan mana berita yang benar. Sebagian besar responden langsung menyebarkan informasi yang diperolehnya dan tidak peduli mengenai dampak negatif apabila berita tersebut ternyata termasuk kategori berita hoaxs. Kemampuan literasi diperlukan untuk mendukung ketahanan nasional. Apabila seseorang tidak memiliki kemampuan literasi yang baik maka kondisi ketahanan pribadinya menjadi lemah yang implikasinya dirinya akan mudah menyebarkan informasi hoaks dan lebih mudah termakan oleh berita hoaks.

\section{DAFTAR PUSTAKA}

Achmadudin Rajab. 2017, Urgensi UndangUndang Nomor 19 Tahun 2016 Tentang Perubahan Atas Undang-Undang Nomor 11 Tahun 2008 Tentang Informasi Dan Transaksi Elektronik Sebagai Solusi Guna Membangun Etika Bagi Pengguna Media, Jurnal Legislasi Indonesia Vol. 14 No. 04 - Desember 2017 : 463 - 472 diakses dari: http:// e-jurnal.peraturan.go.id/index.php/ jli/article/view/128/pdf https://www. google.com/search?sxsrf=ALeKk03F UyeCKwFIJ5RxD8WG5FhzGaJ_LQ\% 
Abdul Haris Subarjo, Wita Setianingsih -- Literasi Berita Hoaxs Di Internet Dan Implikasinya Terhadap Ketahanan Pribadi Mahasiswa

(Studi Tentang Penggunaan Media Sosial Pada Mahasiswa STT Adisutjipto Yogyakarta)

3A1582355245440\&ei $=$ LdNQXrTRGv 2Q4-EP6p21mAw\&q=tujuan+undangundang + ite + pdf\&oq $=$ tujuan + undangundang + ite + pdf \&gs_l $=$ psy-ab.3..33i2 2i29i3017.26347.27621..28522...0.2..0 $.176 .485 .2 \mathrm{j} 2 \ldots \ldots .0 \ldots . . .1 .$. gws-wiz.......0i7 1j0i8i67j0i22i30j33i10.SR6s-Yyqosg\& ved=0ahUKEwj0m8DSzOTnAhV9yDg GHepOCcMQ4dUDCAo\&uact=5 pada tanggal 22 Februari 2020 jam 14:34 wib. Adi Subiyanto, Rizaldi Boer, Edvin Aldrian, Perdinan, Rilus Kinseng, 2018, Isu Perubahan Iklim Dalam Konteks Keamanan Dan Ketahanan Nasional, Jurnal Ketahanan Nasional, Vol. 24, No. 3, Desember 2018: 287-305.

Anonim, 2019, Konflik Tak Berujung di Papua, diakses dari: https://kolom.tempo.co/ read/1254273/konflik-tak-berujungdi-papua/full\&view $=$ ok pada tanggal 15 Maret 2020 jam 16:50 wib.

Anonim, 2020, 3,9 Miliar Orang di Dunia Telah Terhubung Internet diakses dari:https://www.cnnindonesia.com/ teknologi/20181210094556-192352374/39-miliar-orang-di-duniatelah-terhubung-internet. Diakses pada tanggal 22 Februari 2020 jam 12:09 wib.

Anwar Sahid, Edy Suandi Hamid, Armaidy Armawi, 2019, Dampak Implementasi Asas Cabotage dan Program Tol Laut Terhadap Ketahanan Wilayah (Studi Di Kabupaten Kepulauan Anambas, Provinsi Kepulauan Riau), Jurnal Ketahanan Nasional, Vol. 25, No. 2, Agustus 2019: 131-150.

Asosiasi Penyelenggara Jasa Internet Indonesia, 2018, Hasil-Survei-Penetrasi-danPerilaku-Pengguna-InternetIndonesia-2018, diakses dari: https:// www.apjii.or.id/content/read/39/410/
Hasil-Survei-Penetrasi-dan-PerilakuPengguna-Internet-Indonesia-2018, pada tanggal 22 Februari 2020 jam 23:07 wib.

Astri Nur Afidah dan Marshel Doom, 2018, Laporan Tahunan 2018 Kementrian Komunikasi dan Informatika Tahun 2018, diakses dari https://web.kominfo. go.id/sites/default/files/LAPORAN\%20 TAHUNAN $\% 20$ KOMINFO $\% 20$ 2019\%20LOW\%20\%287\%29.pdf, pada tanggal 15 Maret 2020 jam 19:31 wib.

Ayu Yuliani, 2017, Ada 800.000 Situs Penyebar Hoax di Indonesia, diakses dari: https:// kominfo.go.id/content/detail/12008/ ada-800000-situs-penyebar-hoax-diindonesia/0/sorotan_media pada tanggal 23 februari 2020 jam 09:22 wib

Bente R. Walgermo, Jan C. Frijters, Oddny Judith Solheim, 2018, QuarterlyLiteracy interest and reader self-concept when formal readinginstruction begins, Journal Early Childhood Research Quarterly 44, 90-100.

José P. Pezoa, Susana Mendive, Katherine Strasser, 2019, QuarterlyReading interest and family literacy practices from prekindergarten tokindergarten: Contributions from a cross-lagged analysis, journal Early Childhood Research Quarterly 47, 284-295.

Juan D. Borrero, Shumaila Y. Yousafzai, Uzma Javed, Kelly L. Page, 2014, Expressive participation in Internet social movements: Testing the moderating effect of technology readiness and sex on student SNS use, Journal Computers in Human Behavior 30(1), 39-49

Kern, R., 2000, Literacy and Language Teaching. Oxford: Oxford University Press. 
Miechell Octovy Koagouw, 2019, Polisi dan Kominfo Temukan Ratusan Ribu Konten Hoaks Kasus Papua diakses dari: http:// rri.co.id/post/berita/715893/nasional/ polisi_dan_kominfo_temukan_ratusan ribu_konten_hoaks_kasus_papua.html pada tanggal 24 februari 2020 jam 19:56 wib

Puryanti, Y.A.T., 2019, Pembelajaran Pendidikan Pancasila dan Kewarganegaraan Berbasis Literasi Budaya Sebagai Penguatan Identitas Bangsa dalam Handbook Framework Pembelajaran Pendidikan Kewarganegaraan Abad 21, Universitas Negeri Yogyakarta, Yogyakarta. 218-227 Rahadi, D.R., 2017, Perilaku Pengguna Dan Informasi Hoax Di Media Sosial, Jurnal Manajemen dan Kewirausahaan, Volume 5 Nomor 1 Tahun 2017 , Universitas Merdeka, 58-70.

Ronny Scherer dan Fazilat Siddiq., 2019, The relation between students' socioeconomic status and ICT, Journal Computers \& Education 138, 13-32.

Rudi Setiawan, 2019, Kompetensi Profesional Guru PPKn dalam Penguatan Digital Literasi, dalam Handbook Framework Pembelajaran Pendidikan Kewarganegaraan Abad 21, Universitas Negeri Yogyakarta, Yogyakarta. 147-156 Serafina Pastore, Heidi L. Andrade, 2019, Teacher assessment literacy: A threedimensional model, journal Teaching and Teacher Education 84, 128-138.
Subarjo, Abdul Haris, 2016, Pemanfaatan Internet dalam Mata Kuliah Kewarganegaraan, Prosiding Seminar Nasional XI "Rekayasa Teknologi Industri dan Informasi 2016 Sekolah Tinggi Teknologi Nasional Yogyakarta. 427-431.

Subarjo, Abdul Haris, 2017, Perkembangan Teknologi dan Pentingnya Literasi Informasi untuk Mendukung Ketahanan Nasional, Jurnal Angkasa, Volume IX, Nomer 2, November 2017, 1-8.

Wellyana, 2019, Instagram Sebagai Media Pembelajaran Dalam Mata Pelajaran PPKn Tingkat SMA dalam Handbook Framework Pembelajaran Pendidikan Kewarganegaraan Abad 21, Universitas Negeri Yogyakarta, Yogyakarta. 93-100 Wijianto, Muhammad Hendri Nuryadi, Siska Nurdiani, (2019), Relevansi Sumber Belajar Ketahanan Nasional Mata Pelajaran Pendidikan Pancasila Dan Kewarganegaraan Dengan Indikator Pencapaian Kompetensi Siswa (Studi Di Sma Negeri 1 Surakarta, Jawa Tengah), Jurnal Ketahanan Nasional, Vol. 25, No. 3, Desember 2019: 393-408

Yunita, 2017, Ini Cara Mengatasi Berita "Hoax" di Dunia Maya diakses dari: https:// kominfo.go.id/content/detail/8949/inicara-mengatasi-berita-hoax-di-duniamaya/0/sorotan_media pada tanggal 24 februari 2020 jam 23:04 wib. 